\title{
Şakok Armudunun (Pyrus elaeagnifila Pallas) Antioksidan, Antimikrobiyal ve Mutajenik Özelliklerinin İncelenmesi
}

\author{
Zehra Tuğba MURATHAN ${ }^{*} \mathbb{D}$, Nurcan ERBİL ${ }^{2}$, Vesile DÜZGÜNER ${ }^{2}$, Mehmet \\ ARSLAN $^{2}$
}

${ }^{1}$ Ardahan Üniversitesi, Mühendislik Fakültesi, Gıda Mühendisliği Bölümü, Ardahan

${ }^{2}$ Ardahan Üniversitesi, Sağlık Bilimleri Yüksekokulu, Hemşirelik Bölümü, Ardahan

Geliş / Received: 29/11/2018, Kabul / Accepted: 08/03/2019

$\ddot{O} \mathbf{z}$

Şakok armudu (Pyrus elaeagnifila Pallas) doğal olarak yetişen yabani bir armut türüdür. Hasattan sonra olgunlaşır ve yenebilir. Bu çalışma Elazığ'da yetişen şakok armudunun toplam fenolik madde, toplam flavanoid madde, toplam askorbik asit, glutatyon (GSH) ve süperoksid dismutaz (SOD) içeriklerinin; antioksidan aktivite, antimikrobiyal aktivite ve mutajenik aktivitesinin belirlenmesini kapsamaktadır. Elde edilen verilere göre örneklerin toplam fenolik madde içeriği $174.2 \mathrm{mg} \mathrm{GAE}$ (gallik asit eşdeğeri)/100g ekstrakt, toplam flavanoid madde içeriği $44.9 \mathrm{mg} \mathrm{RE}$ (rutin eşdeğeri)/100g ekstrakt, toplam askorbik asit içeriği $14.5 \mathrm{mg} \mathrm{AE}$ (askorbik asit eşdeğeri)/100g ekstrakt, Demir iyonu indirgeyici antioksidan güç (FRAP) değeri $515.6 \mu \mathrm{mol} \mathrm{Fe} \mathrm{(II)/g} \mathrm{ekstrakt,}$ 2,2'-Azino-bis 3-etil benzotiazolin-6-sulfonik asit (ABTS) süpürme aktivitesi \% 53.5, 1,1-difenil-2pikrilhidrazil (DPPH) süpürme aktivitesi $\% 48.2$, GSH içeriği $3.98 \mu \mathrm{M}$ ve SOD içeriği $6.88 \mathrm{U} / \mathrm{ml}$ olarak tespit edilmiştir. Meyve ekstraktının test bakterilerine karşı farklı oranlarda antimikrobiyal aktivite gösterdiği belirlenmiştir. Meyve ekstraktının ön denemeler sonucunda belirlenen altı farklı konsantrasyonunun $(10,20$, 40, 60, 80 and $100 \mu \mathrm{L} /$ plak) Salmonella typhimurium TA 98 ve TA 100 şuşlarına karşı mutajenik aktivite gösterip göstermediği test edilmiş̧ir. Denenen dozların hiçbirinde TA 98 ve TA 100 şuşları üzerinde istatistiksel olarak önemli bir mutajenik etki görülmemiştir. Bu çalışma şakok armudunun önemli biyoaktif bileşenlere, antioksidan ve antimikrobiyal aktiviteye sahip olduğunu ortaya çıkarmıştır.

Anahtar Kelimeler: Radikal süpürücü, Mutajen, Armut, Şakok, Pyrus elaeagnifila Pallas

\section{Investigation of Antioxidant, Antimicrobial and the Mutagenic Properties of Şakok Pear (Pyrus elaeagnifil Pallas)}

\begin{abstract}
Şakok pear (Pyrus elaeagnifila Pallas) is wild pear species growing naturally in Elazı ̆̆ city. After harvesting, the fruit becomes soft and edible. This work covers investigations of total phenolic, total flavanoid, total ascorbic acid, glutathione (GSH), and superoxide dismutase (SOD) contents, antioxidant, antimicrobial,and mutagenic activities of şakok pear. According to the obtained data, $174.2 \mathrm{mg} \mathrm{GAE} / 100 \mathrm{~g}$ extract of total phenolic content, $44.9 \mathrm{mg} \mathrm{RE} / 100 \mathrm{~g}$ extract of total flavanoid content, $14.5 \mathrm{mg}$ AE/100g extract of total ascorbic acid content, $515.6 \mu \mathrm{mol}$ Fe (II)/g extract of Ferric Reducing Antioxidant Power, 53.5\% of 2,2'-Azino-bis (3-ethyl benzothiazoline-6-sulfonic acid) radical scavenging activity, 48.2\% of 1,1-diphenyl-2-picrylhydrazyl radical scavenging activity, $3.98 \mu \mathrm{M}$ of total GSH and $6.88 \mathrm{U} / \mathrm{ml}$ of SOD value were determined. It was identified that şakok pear extract has antibacterial activity at different rates on test bacteria. Six different concentrations determined by pretesting $(10,20,40,60,80$ and $100 \mu \mathrm{L} /$ plate $)$ of pear extracts were performed in Salmonella typhimurium TA 98 and TA 100 strains. TA 98 and TA100 strains, no statistically significant decrease compared to positive control at any dose occurred. The results of this study revealed that the şakok pear has valuable bioactive content, antioxidant and antimicrobial activities.
\end{abstract}

Keywords: Radical scavenging, Mutagen, Pear, Şakok, Pyrus elaeagnifila Pallas

\section{Giriş}

Ülkemiz ekolojik özelliklerinin
yetiştiriciliğe üzerinde bulunması ve ilk çağlardan beri birçok medeniyete ev sahipliği 
yapmasından dolayı çok sayıda meyve tür ve çeşidini barındırmaktadır (Özbek, 1985).

$\mathrm{Bu}$ meyve tür ve çeşitlerinin bir kısmı kültüre alınarak yetiştirilmiştir. Bir kısmı ise doğal olarak yetişmektedir. Doğada kendiliğinden yetişen, daha çok yabani hayvanlar tarafindan tüketilen ve onlara barınma ortamı sağlayan, besleyici özelliği olan meyvelere yabani meyve denmektedir. Yabani meyveler verimsiz topraklarda ve ekstrem koşullarda yetişebilmektedir, bu nedenle doğa şartlarına karşı daha dayanıklı adaptasyonlar geliştirmek zorundadırlar. Kültür meyvelerine oranla daha verimli, kuraklığa dayanıklı, daha çok tohum içeren, daha küçük, ekşi, lifli, buruk, yüksek sekonder metabolit içeren meyvelerdir (Smatana vd., 1988). Bu meyveler gida amaçlı tüketimlerinin yanı sıra 1slah çalışmalarında, ilaç yapımında ve erozyona karşı mücadelede de kullanılmaktadır.

Gıda amaçlı olarak kullanılan meyvelerin sağlığa yararlı etkileri temel olarak içlerinde bulunan biyoaktif bileşiklerden kaynaklanmaktadır. Biyoaktif bileşenler bitkiye tat, renk, koku, aroma veren bileşiklerdir. Fenolik ve flavanoid bileşikler bu gruba girmektedirler. Aynı zamanda bu bileşikler antioksidan potansiyele de sahiptirler ve düzenli olarak tüketildiklerinde birçok hastalığa karş1 koruyucu etkilerinin bulunduğu bilinmektedir (Tripathi and Mishra, 2007).

Anadolu'da yaygın olarak yetişen yabani meyve türlerinden bir tanesi de armuttur. Latince adı Pyrus elaeagnifila olan yabani armut farklı bölgelerde ahlat, çördük, çögür, argun, alfat, çövür, diğdığı, dızdığı, haliç, kerte, kohoz, gelinboğan, çakal armudu, şekok, dă̆ armudu gibi değişik isimler alabilmektedir (Anonim, 2017; Gülgün ve Yazıc1, 2017). Ağacın boyu 10 metreye kadar uzayabilmektedir. İlkbahar ayının ortalarında çiçek açmakta ve sonbahar aylarında meyve hasadı yapılmaktadır. Ağacın iyi gelişmiş kök sistemleri onun erozyon kontrolünde kullanımına olanak sağlamaktadır (Keçeci, 2017).

Elazığ bölgesinde bu armut şakok armudu olarak bilinmektedir. Kültüre alınan armut çeşitleri için iyi bir anaçtır. Ekim ayının ortalarında ham olarak toplanan armutlar sert ve kekremsi, acı bir tada sahiptir. Uygun yerlerde uzun süre saklanabilir. Meyveler oda sıcaklığında bekletildiğinde bir iki hafta kadar sonra yumuşamaya başlamaktadır. Olgun halde bile meyveler kumludur. Bölgede bu meyvenin pekmezi, kurusu, marmelatı, reçeli, sirkesi ve turşusu da yapılarak kış boyunca tüketilmektedir. Pyrus elaeagnifolia meyvelerinin çayı Elazığ bölgesinde idrar söktürücü olarak ta kullanılmaktadır (Çakılcıoğlu vd., 2010).

Meyvelerinin içeriğinde $\mathrm{B}$ vitamini, C vitamini, karoten, pektin, organik asitler, şekerler ve tanen bulunduğu bildirilmiştir (Anonim, 2013). Halk arasında ishale, diş eti hastalıklarına, astıma, rahim iltihabına, böcek sokmalarına, böbrek hastalıklarına, kalp hastalıklarına ve göz hastalıklarına iyi geldiği bilinmektedir (Güdücü, 2014; Keçeci, 2017).

Literatür tarandığında bu armut türüyle ilgili sınırlı sayıda çalışma olduğu görülmektedir. (Güdücü, 2014; Keçeci, 2017; Y1lmaz vd., 2015; Şengül vd., 2018). Elazığ bölgesinde yetişen armut çeşit ve türleri ise daha önce çalışılmamıştır. Meyvelerin biyokimyasal içeriği yetiştikleri iklim ve toprak koşullarından büyük oranda etkilenmektedir. $\mathrm{Bu}$ çalışmanın amacı Elazı ğ ilinde yetişen şakok armutunun toplam fenolik madde, toplam flavanoid madde, toplam askorbik asit, glutatyon (GSH) ve süperoksid dismutaz (SOD) içeriklerinin, antioksidan, antimikrobiyal ve mutajenik aktivitesinin belirlenmesidir. 


\section{Materyal ve Metot}

\subsection{Meyve Materyali}

Çalışmada Elazı̆̆ ilinde doğal olarak yetişen ve bölgede şakok armudu olarak bilinen Pyrus elaeagnifila türüne ait meyve

örnekleri kullanılmıştır. Örnekler 2018 yılı Ekim ayı sonunda hasat edildikten sonra laboratuara getirilmiş, oda sıcaklığında bir hafta bekletilip olgunlaştırıldıktan sonra analizlerde kullanılmıştır.

\subsection{Ekstraksiyon}

Şakok örneklerinin çekirdekleri ayrıldıktan sonra $2 \mathrm{~g}$ meyve eti $20 \mathrm{ml}$ metanol ile homojenize edilmiş ve 24 saat çalkalamalı etüvde, $4{ }^{\circ} \mathrm{C}$ 'de bekletilmiştir. Daha sonra 10 dk 5000 rpm'de santrifüj edilmiştir. 0.136 $\mathrm{mg} / \mathrm{ml}$ derişimindeki süpernatan toplam fenolik madde, toplam flavanoid madde, glutatyon (GSH), süperoksid dismutaz (SOD) ve antioksidan kapasite analizlerinde kullanılmıştır. Askorbik asit tayini için aynı ekstraksiyon metodu uygulanmış ancak çözücü olarak okzalik asit kullanılmıştır.

Antimikrobiyal ve mutajenik aktivite analizleri için 40 gram meyve eti $200 \mathrm{ml} \mathrm{saf}$ su ile homojenize edildikten Antimikrobiyal ve mutajenik aktivite analizleri için 40 gram meyve eti $200 \mathrm{ml}$ saf su ile homojenize edildikten sonra 72 saat, oda sicaklığında ve190 rpm'de ekstrakte edilmiştir. Daha sonra 5000 rpm'de, $10 \mathrm{dk}$ satrifüj edilmiş ve süpernatant ayrılarak rotary evaporatörde konsantre edilmiştir (madde derişimi 2.178 $\mathrm{mg} / \mathrm{ml}$ 'dir). Daha sonra $0.22 \mu \mathrm{m}$ por genişliğine sahip mikrofiltre yardımı ile steril edilmiş ve kullanılana kadar $-20^{\circ} \mathrm{C}$ 'de muhafaza edilmiştir.sonra 72 saat, oda sicaklığında ve190 rpm'de ekstrakte edilmiştir. Daha sonra 5000 rpm'de, 10 dk satrifüj edilmiş ve süpernatant ayrılarak rotary evaporatörde konsantre edilmiştir (madde derişimi $2.178 \mathrm{mg} / \mathrm{ml}$ 'dir). Daha sonra 0.22 $\mu \mathrm{m}$ por genişliğine sahip mikrofiltre yardımı ile steril edilmiş ve kullanılana kadar $20^{\circ} \mathrm{C}$ 'de muhafaza edilmiştir.

\subsection{Top Fenolik Madde, Toplam Flaoid Madde ve Toplam Askorbik Asit Tay}

Toplam olik madde tayini Spanos ve Wrolstad (1992)'a göre Folin-Ciocalteu yöntemi kullanılarak belirlenmiştir. Meyve örneğinin toplam fenolik madde içeriği gallik asit standardı ile mg GAE/100 g ekstrakt olarak hesaplanmıştır.

Toplam flavanoid madde tayini Quettier vd. (2000)'nın yöntemine göre belirlenmiştir. Örneklerin absorbansı 415 nm'de spektrofotometre ile belirlenmiş ve rütin kullanılarak hazırlanmış olan kalibrasyon eğrisinden yararlanılarak $\mathrm{mg} \quad \mathrm{RE} / 100 \mathrm{~g}$ ekstrakt cinsinden hesaplanmıştır.

Toplam askorbik asit tayini AOAC (1990)'a göre spektrofotometrik yöntemle $520 \mathrm{~nm}$ 'de belirlenmiştir. Örneklerdeki askorbik asit miktarı kalibrasyon grafiği ile mg AE/100 g ekstrakt olarak hesaplanmıştır.

\subsection{Antioksidan kapasite tayini}

Örneklerin antioksidan kapasiteleri DPPH (2,2-difenill-1-pikril-hidrazil-hidrat), ABTS (2,2-Azino-bis-3-etilbenzotiazolin-6-sulfonik Asit) ve FRAP (Demir iyonu indirgeyici antioksidan güç) yöntemleri kullanılarak belirlenmiştir. Örneklerin DPPH süpürme aktivitesini belirlemek amaciyla Bakhshi ve Arakawa (2006)'nın metodu kullanılmıştır. Farklı konsantrasyonlarda hazırlanan örnek çözeltilerinin absorbansları spektrofotometrede $515 \mathrm{~nm}$ 'de belirlenmiştir. Kontrol çözeltisi için örnek hacmi kadar metanol eklenerek absorbans tespit edilmiştir. Standart olarak askorbik asit çözeltisi 
kullanılmıştır. $\quad$ \%inhibisyon=(AkontrolAörnek)/Akontrol x100 formülüyle hesaplanmıştır. Örneğin \% 50 inhibisyon konsantrasyonu (IC50) hazırlanan grafik ile hesaplanmıştır.

ABTS yöntemi Re vd. (1999)'na göre yapılmıştır. Örneklerin absorbansı spektrofotometrede 734 nm'de ölçülmüştür. Kör olarak metanol çözeltisi kullanılmıştır. Kontrol çözeltisi için örnek hacmi kadar metanol eklenerek absorbans belirlenmiştir. Antioksidan kapasite \%ABTS inhibisyonu=(Akontrol-Aörnek)/Akontrol $\mathrm{x}$ 100 formülüyle hesaplanmıştır.

FRAP yöntemi Benzie ve Strain (1996)'in metoduna göre yapılmıştır. Örneklerin absorbans1 593 nm'de ölçülmüştür. Kör olarak metanol çözeltisi kullanılmıştır. Standart eğri $\mathrm{FeSO}_{4}$ solüsyonu kullanılarak hazırlanmıştır (100-1000 $\mu \mathrm{l})$. Sonuçlar $\mu \mathrm{mol}$ $\mathrm{Fe}$ (II)/g ekstrakt cinsinden hesaplanmıştır.

\subsection{Gl Glutatyon ve Süperoksit dismutaz Analizleri}

Glutatyon (GSH) düzeyleri Sedlak ve Lindsay (1968) metoduna göre ölçüldü. 5,5-dithiobis2-nitrobenzoic asit ile örneklerdeki GSH'in reaksiyonu ile oluşan son ürün $410 \mathrm{~nm}$ 'de spektrofotometrik olarak okundu. Sonuçlar $\mu \mathrm{M}$ olarak ifade edildi. Süperoksit dismutaz aktivitesi ticari kit (Cayman Chemical 706002) kullanılarak tespit edildi.

\subsection{Antimikrobiyal ve Mutajenik Aktivite Analizleri}

Şakok armudundan elde edilen sulu ekstraktın antimikrobiyal aktivitesi Streptococcus agalactiae ATCC 13813, Bacillus megaterium DSM 32, Staphylococcus aureus ATCC 6538 ve Klebsiella pneumoniae test bakterilerine karşı agar kuyu difüzyon metodu ile test edilmiştir (Collins vd., 1989). Pozitif kontrol olarak ise gentamisin kullanılmıştır. Analiz üç tekrarlı olarak yapılmış ve zon çapları dijital kumpas yardımı ile ölçülmüştür.

Mutajenik aktivite Ames testine göre $S$. typhimurium'un TA 98 ve TA 100 suşları kullanılarak belirlenmiştir (Maron ve Ames, 1983). Şakok armudu ekstraktının $S$. typhimurium'un TA 98 ve TA100 suşları üzerinde letal olmayan dozlarının belirlenmesi için; 16 saat inkübe edilmiş olan bakteri kültürlerinden $(100 \mu l)$ ve Şakok armudu meyve ekstraktının değişik derişimlerinden alınarak $2 \mathrm{ml}$ top agar içerisine eklenmiştir. Homojen bir karışım elde edildikten sonra minimal glukoz agar besiyeri (MGA) bulunan plaklara dökülerek $37^{\circ} \mathrm{C}$ 'de 48-72 saat süre ile inkübe edilmiştir. Daha sonra Şakok armudu meyve ekstraktının değişik derişimlerini içeren plaklarda ve kontrol plaklarında gelişen koloni sayıları karşılaştırılmıştır. Şakok armudu ekstraktının toksik özellik göstermediği gözlenen 6 farkl1 konsantrasyonu $(10,20,40,60,80$ and 100 $\mu \mathrm{L} /$ plate) mutajenite testlerinde kullanılmıştır.

Mutajenite testi için plak inkorporasyon tekniği kullanılmıştır (Maron ve Ames, 1983). İçerisine histidin ve biyotin ekli $2 \mathrm{ml}$ top agar üzerine 16 saatlik bakteri kültürlerinin her birinden $100 \mu \mathrm{l}$ ve Şakok armudunun toksik olmadığ 1 belirlenmiş dozlarından $100 \mu 1$ eklenip homojen bir karışım oluşturulmuş ve MGA besiyeri bulunan plaklara dökülmüştür. TA 98 suşu için 4-nitro-ofenilen daimin (4NPD) (100 $\mu \mathrm{g}$ petri-1), TA 100 suşu için sodyum azid (SA) $(10 \mu \mathrm{g}$ petri-1) pozitif kontrol olarak kullanılmıştır. Çalışmalar üç tekrarlı yapılmış, petriler $37^{\circ} \mathrm{C}$ 'de $48-72$ saat inkübasyona bırakılmıştır. Kontrol ve test plaklarında gelişen revertant koloni sayıları belirlenerek istatistiksel olarak karşılaştırılmıştır.

\section{7. İstatistiksel Analizler}

Her analiz üç tekrarlı olarak yapılmıştır. İstatistiksel değerlendirmelerde SPSS 16 
programı kullanılmıştır. Mutajenite analizlerinde Dunnett testi kullanılmıştır. Elde edilen veriler 0.05 anlam seviyesinde yorumlanmıştır.

\section{Bulgular ve Tartışma}

Günümüzde gıda takviyesi olarak kullanılan yapay antioksidanların toksik ve kanserojenik etkilere sahip oldukları belirlendiğinden, doğal antioksidan kaynakları daha popüler hale gelmiştir. Antioksidan özellikleri bilinen fenolik bileşikler meyvelerin kendilerine özgü renk, tat ve aroma kazanmalarında rol alan ve meyvenin kalitesini oluşturan bileşiklerdir. $\mathrm{Bu}$ bileşikler bitkinin hayati fonksiyonlarının sürdürülmesinde görev almadıkları için sekonder metabolitler olarak ta adlandırılmaktadırlar. $\mathrm{Bu}$ bileşikler bitkide enfeksiyon, yaralanma, UV radyasyon gibi stres koşullarına tepki olarak bol miktarda sentezlenmektedir. Fenolik bileşiklerin antioksidan potansiyelleri sayesinde kanser, diyabet, kalp hastalıkları, katarakt gibi birçok hastalıktan korunmada etkin oldukları bilinmektedir (Justesen ve ark., 1998; Naczk ve Shahidi, 2006). Flavanoidler ise fenolik bileşiklerin bir grubudur. Antiradikal, antibiyotik, antialerjen, antiinflamatuar özelliklere sahiptirler (Coşkun, 2005).

Çalışmamızda şakok meyvelerinin metanolik ekstraktlarında toplam fenolik madde içeriğinin $174.2 \mathrm{mg}$ GAE/100g ekstrakt, toplam flavanoid madde içeriğinin $44.9 \mathrm{mg}$ $\mathrm{RE} / 100 \mathrm{~g}$ ekstrakt olduğu tespit edilmiştir. Daha önce bu meyveyle ilgili yapılmış birkaç çalışma mevcuttur. Baltas (2017) Antalya'dan topladığ 1 . elaeagnifila meyvelerinin toplam fenolik madde içeriğini $4.98 \mathrm{mg}$ GAE/g ekstrakt olarak tespit etmiştir. Şengül vd. (2018) ise bu meyvenin marmelatında toplam fenolik madde içeriğinin $205.75 \mu \mathrm{g}$ GAE/g ekstrakt olduğunu belirlemişlerdir. Aynı araştırıcılar marmelat örneklerinde yaptıkları fenolik bileşen analizlerinde $2.28 \mathrm{mg} / \mathrm{kg}$ gallik asit, $1.07 \mathrm{mg} / \mathrm{kg}(+)$ kateşin, $0.37 \mathrm{mg} / \mathrm{kg}$ (-) epikateşin, $0.32 \mathrm{mg} / \mathrm{kg}$ klorojenik asit, 0.21 $\mathrm{mg} / \mathrm{kg}$ kafeik asit, $15.63 \mathrm{mg} / \mathrm{kg}$ p-kumarik asit, $2.78 \mathrm{mg} / \mathrm{kg}$ hesperidin, $3.85 \mathrm{mg} / \mathrm{kg}$ elajik asit ve $0.79 \mathrm{mg} / \mathrm{kg}$ kuersetin bulunduğunu tespit etmişlerdir. Güdücü (2014) $P$. elaeagnifila meyvelerinin aseton ve metanol ekstraktlarında toplam fenolik madde miktarının sirasıyla 49.81 ve $28.91 \mu \mathrm{g}$ $\mathrm{GAE} / \mathrm{mg}$ ekstrakt olduğunu, aseton ekstraktlarının metanolik ekstraktlara oranla daha yüksek fenolik madde içerdiğini bildirmiştir. Yılmaz vd. (2015) İç Anadolu Bölgesi'nden topladıkları $P$. elaeagnifila meyvelerinin toplam fenolik madde içeriğinin 42.79-119.14 mg GAE/100 g ekstrakt arasında olduğunu bildirmişlerdir. Bitkilerin içerdiği fenolik bileşiklerin miktarı yetişme ortamının toprak yapısına, iklimsel koşullarına, hasat zamanına, bitkinin güneş 1şı̆̆ından yararlanma süresine, depomla şartlarına ve kültürel uygulamalara bağlı olarak değişebilmektedir. Aynı zamanda in vitro koşullarda kullanılan çözücüye ve metoda göre değişiklik göstermektedir (Heimler vd., 2006).

Tablo 1. P.elaeagnifila Meyve Örneklerinin Bazı Biyoaktif Bileşen ve Antioksidan Aktivite Sonuçları

\begin{tabular}{|c|c|c|c|c|}
\hline $\begin{array}{l}\text { Toplam Fenolik } \\
\text { Madde } \\
(\mathrm{mg} / \mathbf{1 0 0 g})\end{array}$ & $\begin{array}{l}\text { Toplam } \\
\text { Flavanoid } \\
\text { Madde } \\
(\mathrm{mg} / \mathbf{1 0 0 g})\end{array}$ & $\begin{array}{l}\text { Toplam } \\
\text { Askorbik Asit } \\
\text { (mg/100g) }\end{array}$ & $\begin{array}{l}\text { FRAP } \\
(\mu \mathrm{mol} / \mathrm{g})\end{array}$ & $\begin{array}{l}\text { DPPH radikal ABTS } \\
\text { süpürücü aktivite }(\%) \\
\text { IC }_{50} \\
(\mu \mathrm{g} / \mathrm{ml})\end{array}$ \\
\hline $174.2 \pm 7.5$ & $44.9 \pm 0.5$ & $14.58 \pm 1.1$ & $515.6 \pm 2.9$ & $6.89 \pm 0.014$ \\
\hline $\begin{array}{l}\text { Askorbik } \\
\text { hasara ka }\end{array}$ & $\begin{array}{l}\text { asit bit } \\
\text { arş1 koruya }\end{array}$ & $\begin{array}{l}\text { hücre } \\
\text { ir bileşik }\end{array}$ & $\begin{array}{l}\text { oksidatif } \\
\text { Smirnoff, }\end{array}$ & $\begin{array}{l}\text { 1996). Tablo 1'de görüldüğ̈̈ gibi şakok } \\
\text { meyvelerinin toplam askorbik asit içeriği } \\
14.58 \mathrm{mg} \text { AE/100g ekstrakt olarak } \\
\text { belirlenmiştir. Abacı vd. (2016) Ardahan }\end{array}$ \\
\hline
\end{tabular}


yöresinde banda adiyla bilinen yabani armut meyvelerinin toplam askorbik asit içeriğinin $10.2 \mathrm{mg} \quad \mathrm{AE} / 100 \mathrm{~g}$ ekstrakt olduğunu bildirmişlerdir. Sanchez-Moreno vd. (2003) $P$. communis meyvelerinde toplam askorbik asit miktarının 2.6 ile $5.3 \mathrm{mg}$ AE/100g ekstrakt arasında değiştiğini bildirmişlerdir.

Şakok örneklerinin antioksidan aktivite analiz sonuçları Tablo 1'de görülmektedir. Örneklerin antioksidan kapasiteleri üç farklı metoda göre belirlenmiştir. DPPH metodunun temeli DPPH radikali ile etkileşime giren bitki ekstraktındaki antioksidanların yüzdesine dayanmaktadır. FRAP metodunun temeli antioksidanlar içeren bir örneğin oksidan özellikte olan ferik formdaki demiri ferro formuna indirgeme gücüne dayanır. ABTS metodunun temeli ise ABTS radikali ile etkileşime giren bitki ekstraktındaki antioksidanların yüzdesi temeline dayanmaktadır (Parejo vd., 2000; Mbaebie vd., 2012). Çalışmamızda örneklerin FRAP değeri $515.6 \mu \mathrm{mol} / \mathrm{g}$ ekstrakt, ABTS radikali süpürme aktivitesinin \% 48.2, DPPH radikali süpürme aktivitesinin IC50 değerinin 33.2 $\mu \mathrm{g} / \mathrm{ml}$ olduğu tespit edilmiştir. Güdücü (2014) $P$. elaeagnifila meyvelerinin beş faklı konsatrasyonda (50, 100, 250, 500, 1000 $\mu \mathrm{g} / \mathrm{mL}$ ) hazırlanan metanol ve aseton ekstraktlarında DPPH radikali giderme aktivitesinin konsatrasyona bağlı olarak değiştiğini belirlemiştir. En yüksek aktivitenin ( $\%$ 89.23) asetonla hazırlanan $1000 \mu \mathrm{g} / \mathrm{mL}$ konsantrasyondaki ekstraktlarda olduğu, en düşük aktivitenin (\% 13.89) ise metanolle hazırlanan $100 \quad \mu \mathrm{g} / \mathrm{mL}$ konsantrasyondaki ekstraktlarda olduğu bildirilmiştir. Şengül vd. (2018) ise $P$. elaeagnifila meyvelerinden elde edilen marmelatta DPPH radikali süpürme aktivitesini, çalışmamızda tespit ettiğimiz değerden çok daha düşük $\left(\begin{array}{ll}\% & 3.56\end{array}\right)$ bulmuşlardır. $\mathrm{Bu}$ durumun marmelat hazırlarken meyvenin 1sıl işlem görmesi sonucu antioksidan aktiviteye sahip bileşenlerin miktarında azalma meydana gelmesiyle açıklayabiliriz.

Bitkilerin yapısında bulunan ve antioksidan aktiviteye sahip bileşenlerden birisi de glutatyondur. Glutatyon (GSH) bir tripeptit olup, hücreyi oksidatif ve diğer çevresel streslerin oluşturduğu zarara karşı korumakta görev yapmaktadır (Smirnova ve Oktyabrsky, 2005). Yine bitki yapısında bulunan enzimatik antioksidanlardan olan süperoksit dismutaz (SOD) süperoksit radikalini $\left(\mathrm{O}_{2 .-}\right)$ hidrojen peroksit $\left(\mathrm{H}_{2} \mathrm{O}_{2}\right)$ ve moleküler oksijene $\left(\mathrm{O}_{2}\right)$ katalizleyen enzimatik bir antioksidandır (Young, 2001). Çalışmamızda şakok meyve örneklerinin total GSH miktarının $3.98 \mu \mathrm{mol}$, SOD aktivitesinin ise $6.89 \mathrm{U} / \mathrm{mL}$ olduğu belirlenmiştir.

Şakok örneklerinin antimikrobiyal ve antimutajenik aktivite sonuçları Tablo 2 ve Tablo 3'te görülmektedir. Şakok armudu sulu ekstraktının Streptococcus agalactiae ATCC 13813, Bacillus megaterium DSM 32, Staphylococcus aureus ATCC 6538 ve Klebsiella pneumoniae'ye karşı faklı oranlarda antimikrobiyal aktiviteye sahip olduğu belirlenmiştir. Çalışmamızdaki sonuçlardan farklı olarak Güdücü (2014) $P$. elaeagnifila meyvelerinin metanol ve aseton ekstraktlarının 4 farklı konsatrasyonunun (50, 100, 200, $500 \mathrm{mg} / \mathrm{mL}) \quad 7$ bakteri (Staphylococcus aureus ATCC29213, Klebsiella pneumonia ATCC33495, Enterococcus faecalis ATCC29212, Pseudomonas aeruginosa ATCC27853, Enterobacter cloacae ATCC13047, Serratia marcescens, Escherichia coli ATCC25923) üzerinde inhibisyon zon çap1 oluşturmadığını ve antimikrobiyal aktivitesinin olmadığını belirlemiştir. Erbil vd. (2018) farklı armut çeşitleriyle yaptıkları bir çalışmada en yüksek antimikrobiyal aktiviteye Pseudomonas aeroginosa ATCC 9027'ya karş1 20.14 mm inhibisyon çap1 ile Banda armudunun, en düşük aktiviteye ise Escherichia coli'ye karş1 $12.34 \mathrm{~mm}$ inhibisyon çapıyla Güğüm armudunun sahip olduğunu bildirmişlerdir. 
Antimikrobiyal aktivite çalışmalarında farklı sonuçlar bildirilebilmektedir. Gözlenen bu farklılıklar numunenin yetiştiği iklim koşulları ve coğrafik koşullara bağlı olarak bitki içeriğinin değişmesi, kullanılan mikroorganizma tür ve/veya suşlarının faklı olması, farklı ekstraksiyon yöntemleri ve/veya çözücü seçimi gibi faktörlerden kaynaklanabilmektedir

Tablo 2. P. elaeagnifila Meyve Örneklerinin Antimikrobiyal Aktivite Sonuçları

\begin{tabular}{lll}
\hline Bakteri & Şakok armudu (mm) & Gentamisin $(\mathbf{m m})$ \\
\hline Streptococcus agalactiae ATCC 13813 & $30.68 \pm 0.43$ & $32.58 \pm 0.35$ \\
Bacillus megaterium DSM 32 & $23.59 \pm 0.47$ & $29.69 \pm 1.43$ \\
Staphylococcus aureus ATCC 6538 & $24.97 \pm 2.13$ & $34.33 \pm 1.61$ \\
Klebsiella pneumoniae & $24.58 \pm 0.96$ & $29.77 \pm 1.31$ \\
\hline
\end{tabular}

Daha önce de belirtildiği gibi günümüzde doğal antioksidan kaynakları olan bitkisel ürünlere olan ilgi artmıştır. Bitki hücreleri kompleks birçok fitokimyasal içermektedir. $\mathrm{Bu}$ fitokimyasalların belli bir dozun üzerinde alınması toksik veya mutajenik etki oluşturabilmektedir (Wan-Ibrahim vd., 2010).
$\mathrm{Bu}$ nedenle bitkisel ürünlerin mutajenik aktivitelerinin bilinmesi de büyük önem taşımaktadır. Çalışmamızda meyve ekstraktlarının denenen altı konsantrasyonunun S. typhimurium TA 98 ve TA100 suşları üzerinde istatistiksel olarak kontrol ve pozitif kontrole göre mutajenik aktivite oluşturmadı̆̆ belirlenmiştir.

Tablo 3. P. elaeagnifila Meyve Örneklerinin Mutajenite Sonuçları

\begin{tabular}{lll}
\hline & TA98 & TA100 \\
\hline Kontrol & $15.67 \pm 1.20$ & $95.3 \pm 19.8$ \\
$\mathbf{P K}^{+}$ & $2123 \pm 151$ & $2179 \pm 208$ \\
$\mathbf{1 0 0} \boldsymbol{\mu L} /$ plate & $31.67 \pm 2.60$ & $63.33 \pm 7.54$ \\
$\mathbf{8 0} \boldsymbol{\mu L / p l a t e}$ & $22.33 \pm 2.40$ & $57.000 \pm 0.577$ \\
$\mathbf{6 0} \boldsymbol{\mu L / p l a t e}$ & $30.00 \pm 5.51$ & $65.000 \pm 0.577$ \\
$\mathbf{4 0} \boldsymbol{\mu L / p l a t e}$ & $38.67 \pm 8.97$ & $67.3 \pm 10.7$ \\
$\mathbf{2 0} \boldsymbol{\mu L} /$ plate & $16.33 \pm 2.19$ & $66.667 \pm 0.882$ \\
$\mathbf{1 0} \boldsymbol{\mu L / p l a t e}$ & $31.00 \pm 8.08$ & $64.67 \pm 4.18$ \\
\hline
\end{tabular}

\footnotetext{
*: kontrol ile aradaki fark önemlidir.
} 
PK:Pozitif kontrol

+: TA 98 suşu için 4-nitro-ofenilen daimin (4-NPD) (100 $\mu \mathrm{g}$ petri-1), TA 100 suşu için sodyum azid (SA) (10 $\mu \mathrm{g}$ petri-1) pozitif kontrol olarak kullanılmıştır.

Sonuç olarak şakok armudunun askorbik asit, fenolik maddeler gibi sağlık için önemli fitokimyasallar içerdiği belirlenmiştir. $\mathrm{Bu}$ fitokimyasallar aynı zamanda meyvenin antioksidan ve antimikrobiyal özelik kazanmasını da sağlamaktadır. Çalışmada meyve ekstraktının orta düzeyde antioksidan aktivite sergilediği görülmektedir. Aynı zamanda insan patojeni olan bakterilere karşı antimikrobiyal aktiviteye sahip olması da büyük önem taşımaktadır. Bütün bu özelliklerinin yanı sıra ekstraktların hiçbir dozunda mutajenik etki görülmemesi şakok armudu meyvelerinin insanlar için alternatif bir gida kaynağı olarak rahatlikla kullanılabileceğini göstermektedir.

\section{Kaynaklar}

Abac1, Z.T., Sevindik, E., Ayvaz, M. 2016. Comparative study of bioactive components in pear genotypes from Ardahan/Turkey. Biotechnology \& Biotechnological Equipment, 30, 1, 3643.

Anonim 2013. Ahlat bitkisi nedir, nasil kullanılır? (http://www.hastalıktedavi.net), Son erişim tarihi: 19.11.2018

Anonim

https://www.1organik.com/ahlat-agaciahlat-armudu.html, Son erişim tarihi: 19.11.2018

AOAC, 1990. Official methods of analysis of the Association of Official Analytical Chemists, 15th ed., Arlington VA, 1058-1059.

Aslan, G., Yazıc1, K. 2017. Doğanın Bize Sunduğu Görsel Şölen Yabani Meyveler I. Türktob, 21, 60-64.

Bakhshi, D., Arakawa, O. 2006. Effects of UV-b irradiation on phenolic compound accumulation and antioxidant activity in 'Jonathan' apple influenced by bagging, temperature and maturation. Journal of Food, Agriculture \& Environment, 4, 1, 75-79.

Baltas, N. 2017. Investigation of a wild pear species (Pyrus elaeagnifolia subsp. Elaeagnifolia Pallas) from Antalya, Turkey: polyphenol oxidase properties and anti-xanthine oxidase, anti-urease, and antioxidant activity. International Journal of Food Properties, 20, 3, 585595.

Benzie, I.F.F, Strain, J.J. 1996. The ferric reducing Ability of plasma (FRAB) as a measure of Antioxidant power: The FRAB assay. Analytical Biochemistry, 239, 70-76.

Collins, C.M., Lyne, P.M., Grange, J.M., 1989. Antimicrobial sensitivity and assay tests. Collins and Lyne's Microbiological Methods. Butterworths, London

Coşkun, T., 2005. Fonksiyonel besinlerin sağlı̆̆ımız üzerine etkileri. Çocuk Sağlığı ve Hastalıkları Dergisi, 48, 6984.

Çakılcığlu, U., Şengün, M.T., Türkoğlu, D. 2010. An ethnobotanical survey of medicinal plants of Yazıkonak and Yurtbaşı districts of Elazı $\breve{g}$ province, Turkey. Journal of Medicinal Plants Research, 4, 7, 567-572.

Heimler, D. Vignolini, P. Dini, M.G. Vincieri, F.F. Pomani, A. 2006. Antiradical activity and polyphenol composition of local Brassicaiceae adible varieties. Food Chemistry, 99, 464-469. 
Erbil, N., Murathan, Z. T., Arslan, M., Ilcim, A., Sayin, B. 2018. Antimicrobial, Antioxidant, and Antimutagenic Activities of Five Turkish Pear Cultivars. Erwerbs-Obstbau, 60, 3, 203 209.

Güdücü, F. 2014. Pyrus elaeagrifolia bitkisi ekstrelerinin fenolik madde içerikleri, DPPH radikali giderme aktiviteleri ve in vitro antimikrobiyal etkilerinin belirlenmesi. Master's thesis, Trakya Üniversitesi.

Justesen, U., Knuthsen, P., Leth, T. 1998. Quantitative analysis of flavonols, flavones, and flavonones in fruits, vegetables and beverages by highperformance liquid chromatography with photodiode array and massspectrometric detection. Journal of Chromatography A, 799, 101-110.

Keçeci, L. D. 2017. Hakkari yöresi üstün nitelikli ahlat (Pyrus elaegrifolia L.) genotiplerinin bazı özelliklerinin belirlenmesi. Master's thesis, Adnan Menderes Üniversitesi, Fen Bilimleri Enstitüsü.

Maron, D., Ames, B. 1983. Revised Methods for the Salmonella Mutagenicity Test. Mutation Research, 113, 173-215.

Mbaebie, B.O., Edeoga, H.O., Ajelayan, A.J. 2012. Phytochemical analysis and antioxidant activities of aqueous bark extract of Schoba lahtolic JACQ. Asian Pacific Journal of Tropical Biomedicine, 2, 118-124.

Naczk, M., Shahidi, F. 2006 Phenolics in cereals, fruits and vegetables: Occurence, extraction and analysis. Journal of Pharmaceutical and Biomedical Analysis 41, 1523-1542.

Nizamoğlu, N.M., Nas, S. 2010. Meyve ve Sebzelerde Bulunan Fenolik Bileşikler; Yapıları ve Önemleri. Gida
Teknolojileri Elektronik Dergisi, 5, 1, 20-35.

Özbek, S. 1985. Genel Meyvecilik. Çukurova Üniversitesi Ziraat Fak. Yayınları Ders Kitab1, 386.

Parejo, L., Codina, C., Petrakis, C., Kefalas, P. 2000. Evaluation of scavenging activity assessed by $\mathrm{Co}$ (II)/EDTAinduced luminol chemiluminescence and DPPH center dot (2,2-diphenyl-1picrylhydrazyl) free radical assay. Journal of Pharmacological and Toxicological Methods, 44, 507-512.

Quettier-Deleu, C., Gressier, B., Vasseur, J., Dine, T., Brunet, J., Luyck, M., Cazin, M., Cazin, J.C., Bailleul, F., and Trotin, F. 2000. Phenolic compounds and antioxidant activities of buckwheat (Fagopyrum esculentum Moench) hulls and flour. Journal of Ethnopharmacology, 72, 35-40.

Re, R., Pellegrini, N., Proteggente, A., Pannala, A., Yang, M., and Rice-Evans, C. 1999. Antioxidant activity applying an improved ABTS radical cation decolorization assay. Free Radical Biology and Medicine, 26, 9/10, 12311237.

Sanchez-Moreno C, Plaza L, De Ancos B, et al. 2003. Quantitative bioactive compounds assessment and their relative contribution to the antioxidant capacity of commercial orange juices. $\mathrm{J}$ Sci Food Agr. 83, 430-439.

Sedlak, J., Lindsay, R.H. 1968. Estimation of Total Protein-Bound, and Nonprotein Sulfhydryl Groups in Tissue with Ellman's Reagent. Analytical Biochemistry, 25, 1, 192-205.

Smatana, L., Kytka, J., Kadarova, S. 1988. Results of Breeding and Groving Minor Fruit Species in Czechoslovakia. Acta Horticulture, 224, 83-87. 
Smirnoff N. 1996 The function and metabolism of ascorbic acid in plants. Ann Bot. 78, 661-669.

Smirnova, G.V., Oktyabrsky, O.N. 2005. Glutathione in Bacteria. Biochemistry (Moscow), 70 11, 1199-1211.

Spanos, G.A., Wrolstad, R.E. 1992. Phenolic of apple, pear and white grape juices and their changes with processing and storage. Journal of Agriculture and Food Chemistry, 40, 9, 1478-1487.

Şengül, M., Topdaş, E.F., Doğan, H., Serencam, H. 2018. Artvin İlinde Geleneksel Olarak Üretilen Bazı Marmelat Çeşitlerinin Çeşitli Fiziksel ve Kimyasal Özellikleri ile Antioksidan Aktiviteleri ve Fenolik Profillerinin Araştırılması. Akademik Gıda, 16, 1, 51-59.

Tripathi K, Mishra AS. 2007. Glucosinolates in animal nutrition: A review. Anim Feed Sci and Technol, 132, 1-27.

Wan-Ibrahim, W.I., Sidik, K. and Kuppusamy, U.R. 2010. A high antioxidant level in edible plants is associated with genotoxic properties. Food Chemistry, 122, 4, 1139- 1144.

Yilmaz, K.U., Ercisli, S., Cam, M., Uzun, A., Yilmaztekin, M., Kafkas, E., Pinar, H. 2015. Fruit Weight, Total Phenolics, Acidity and Sugar Content of Edible Wild Pear (Pyrus elaeagnifolia Pall.) Fruits. Erwerbs-Obstbau, 57, 4, 179184.

Young IS, Woodside JV. 2001. Antioxidants in Health and Disease. J Clin Pathol. 54, 3, 176-186. 